\title{
Liselerde Kültürler Arası Bir Uygulama Örneği Olarak Kanada Programı: Tarih Dersleri Üzerine Öğrenci Görüssleri
}

\author{
Funda $\mathrm{KOCA}^{28}$ \\ Özel Enka Teknik ve Endüstri Meslek Lisesi \\ Makine Organize Sanayii Bölgesi Demirciler Köyü / Dilovası / Kocaeli / Türkiye \\ Doç. Dr. Ahmet Şimşek* \\ Sakarya Üniversitesi, Eğitim Fakültesi, \\ Ortaöğretim Sosyal Alanlar Eğitimi Bölümü, Tarih Eğitimi A.B.D. Hendek / Sakarya / Türkiye
}

\begin{abstract}
Özet
Kültürler arasılık bugünün dünyasında önemli bir bakış açısı sayılmaktadır. Haberleşme imkânlarının artmasıyla dünya üzerinde var olan kültürlerin etkileşiminin arttığı bilinmektedir. Bu durum her topluluğun kendi kültürünün ve kimliğinin genç nesillere öğretilmesi yanında “öteki” kültür ve kimliklerin de öğretilmesini beraberinde getirmiştir. Genç bireylere başka kültürlere karşı müsamahakâr ve demokratik bir bakış açısı kazandırılması, farklı yaşam tarzlarının barış içinde birlikte yaşamasının temini için kültürler arası bir yaklaşımla eğitimin biçimlendirilmesi bugün sosyal bir ihtiyaç olarak görülmektedir. Bu araştırmada bir kültürler arası eğitim faaliyeti olarak Kanada Lise Diploması Programı’ nda okuyan lise öğrencilerinin konuya bakışları tarih
\end{abstract}

28 Marmara Üniversitesi Eğitim Bilimleri Enstitüsü Tarih Eğitimi Doktora Öğrencisi

* Sorumlu Yazar. Tel:+90 2646150196 - 97 E-posta: simsek@sakarya.edu.tr

(C) 2011 Kalem Eğitim ve Sağlık Hizmetleri A.Ş. Bütün Hakları Saklıdır ISSN: 2146 - 5606 
eğitimi bağlamında incelenmiştir. Bu programı uygulayan İstanbul'da özel bir lisenin 9, 10, 11 ve 12. sınıflarından toplam 19 öğrenci ile tarih eğitimi açısından yaşadıkları farklılıklar sorgulanmaya çalışılmıştır. Amaçlı örneklem çalışma grubundan yarı yapılandırılmış bireysel mülakat yoluyla veriler toplanmıştır. Araştırmada betimsel analiz yöntemi benimsenmiştir. Araştırma sonunda programa katılan öğrencilerin Kanada programı tarih eğitimini daha esnek, daha kolay, daha barışçıl ve açık buldukları görülmüştür. Bu gelişmenin lise düzeyinde öğrenim gören Türk öğrencilerinin tarih eğitimine yükledikleri genel anlamı olumlu biçimde iyileştirdiği söylenebilir.

Anahtar Sözcükler: Tarih eğitimi; Kanada okul programı; Kültürler arası eğitim.

\title{
The Canadian Programme as an Intercultural Application in High Schools: The Students' Opinions at History Course
}

\begin{abstract}
In today's world, interculturality is considered as an important point of view. It is known that with the increase of communication possibility, the interaction of existing culture over the World is increasing too. Along with teaching their own culture and identity this situation has brought the teaching of other cultures and identities. In order to make the youth more tolerant towards other cultures and give them a democratic point of view and to make possible for different life styles to co-exist; reforming the education by intercultural approach is seen as a social necessity. In this research the point of views of high school students those study in Canadian High School Diploma Program have been surveyed in according to terms of history education. With 19 students from 9, 10, 11 and 12th grades, their diversity of history education was questioned, the students were from a private school in Istanbul. Data has been gathered from semi-structured interview which were selected purposeful sample. Descriptive analysis method was favored in the research. It has been observed that the students that attended the research have found the Canadian history education to be more flexible, peaceful, definite and easier. It can be said that this profession has
\end{abstract}


improved the high school grade Turkish students' ascribing to general view history education in a positive fashion.

Key Words: History education; Canadian school program; Intercultural education.

\section{Giriş}

Soğuk savaşın sona ermesiyle başlayan yeni dönem "bilgi toplumu" kavramı çerçevesinde anılmaya başlamıştır. Yeni dönemin ortaya çıkardığı zorunluluklardan biri hızla artan bilgi birikimi karşısında çağdaş bilgi ve beceri donanımına sahip bireyler yetiştirmenin amaçlanması olmuştur. Bunun doğal sonucu olarak da eğitim paradigması değişmiştir. Yeni eğitim anlayışında sınıflarda yapılan ders yerine bireysel araştırmalar, yalnız çalışma yerine ekiple öğrenme, pasif özümseme yerine çıraklık, her şeyi bilen öğretmen yerine rehber öğretmenlik, değişmeyen içerik yerine esnek içerik kadar, homojenlik yerine de çeşitlilik ön plana çıkmıştır (Genç ve Eryaman, 2007). Yine eğitimin salt okur-yazarlık misyonu yerine yüksek düzeyde okur-yazarlık hedeflenmiştir. Çünkü bilgi çağında eğitim; toplumların birbirlerine sınırlarla kapalı olduğu ve birbirleri arasında etkileşimin az olduğu önceki dönemlerdeki gibi belirli değerleri aktaran ve önceki kuşakların yaptıklarını yineleyen değil, yeni şeyler yapabilme yeteneğine sahip insanlar yetiştirmeyi temel amaç edinmiştir (Erdoğan, 1998, s.93).

Eğitimdeki bu kökten dönüşümün nedeni olarak sadece psikolog ve pedagogların öğrenme merkezli araştırma bulgularını değil, aynı zamanda dünyadaki 1990'lı yıllardan sonra ortaya çıkan siyasi gelişmeleri de hatırlamak gerekir. SSCB'nin dağılmasıyla "kapitalist dünyanın" "sosyalist dünya" karşısında tescillenen üstünlüğü, devletlerin siyasal ve ekonomik sistemlerinde "birey" merkezli yönelimleri beraberinde getirmiştir. Küreselleşme olarak adlandırılan bu yeni dönem, dünya çapında 
hem bireylerin hem de toplumların ilişkiler ağının yeniden tanımlanmasını zorunlu kılmıştır. Küresel kapitalist sistemde ulusdevletlerin çizdiği ekonomik sınırların ortadan kalkması ile ulusal sınırlar içinde yaşayan insan topluluklarının kapitalizmin yeni ihtiyaçlarına uygun kendi kültürel ve yerel durumlarının temsiline imkân tanıyan bir sistem ortaya atılmıştır. Yeni kapitalist sistemde demokrasi kavramı merkezinde eskiden tanınmayan kültürel hakların tanındığı, farklı kültürlerin yaşamalarına imkân sağlandığı iddiaları yer almıştır. Bununla egemen olmayan kültürlerin kendilerini ifade etme fursatları önemsenmiş, egemen olanın imkânlarına kavuşmaları amaçlanmıştır. Böylelikle eskiden ulus devletler için sorun olan farklı kültürel toplulukların, yeni düzende sorunsuz biçimde piyasa sistemine eklenmesi hedeflenmiştir (Dördüncü Demokratik Eğitim Kurultayı, 2004, s.3). Bu sürecin olumlu tarafı ise konu bağlamında bilgi merkezlerinin artmasıyla paylaşımın kolaylaşması, bireylerin küresel anlamda serbest dolaşımının yoğunlaşması, bununla birlikte kültürler arası iletişim ve diyaloğun kendisini içkin şekilde hissettirmesi sayılabilir (Yağbasan, 2008, s.310). Bu bağlamda "kültürel çevre" kavramı sürekli genişlemiş, gittikçe çeşitlenmiştir. Yine bu dönemde başka toplum ve ulusların yoğun alışverişini zorlaştıran uluslaşma düşüncesinin esneyerek yeni bir biçim kazanmaya doğru yöneldiği görülmüştür. Böylece "kültürel çeşitliliğin olumsuz bir durum olmadığı" olgusu genel kabul görmeye başlamıştır. Zira sınır ötesi göçler, azınlıkların istekleri, küreselleşmenin ortaya çıkardığı ekonomik, siyasi ve iletişimsel etkiler, dünyadaki tüm din ve inançların artan etkileşimi ile bütün bunları destekleyen ve yeniden üreten kapitalist sistemin bilgi-iletişim araçlarındaki gelişmeler buna neden olmuştur.

Birey, gittikçe sayıları artan çok kültürlü ortamlarda yeni tarz bir yaşamı fark etmiş ve aidiyet duyduğu ya da ilişkide olduğu çok sayıda kültürel ilişkiyi yönetmek durumunda kalmıştır. Diğer taraftan, kültürel çeşitliliğin bu şekilde yoğunlaşması yeni sosyal ve politik mücadele 
şekillerine eşlik etmiştir. Kültürel çeşitlilik gruplar için çoğu kez korku ve reddetmeyi doğurmuş, bunun sonucu ortaya çıkan 1 rkçılık, yabancı düşmanlığı, hoş görüsüzlük ve şiddet kullanımı toplumların yapısını ve huzurunu tehdit etmiştir. Çözüm olarak farklı kültürel kimliklerin olduğu bir dünyada birlikte yaşamanın yolları aranmaya başlamıştır. Bu sebepten eğitime yeni misyonlar yüklenmiş, bu sorunlara çözüm sunabilecek dört yeni ilke ortaya atılmıştır. Bunlar; öğrenmeyi bilme, öğrenmeyi öğrenme, bireysel öğrenme yanında birlikte yaşamayı öğrenme olarak belirlenmiştir (Akçay, 2003, s.7). Böylece küreselleşen dünya ile uyum ya da yaşadığ 1 toplumların hâkim kültürlerine entegre sorunuyla başa çıkabilecek bireyler yetiştirmek kadar, toplumsal değişim ile beliren yeni sorunları fark edip bunların çözümü üzerine düşünen, kendini "yaşam içinde öğrenmeye" yönelten nesiller hedeflenmiştir.

\section{Kültürler Arası Ĕgitim}

Kültürler arası (interculturel) eğitim, farklı kültürlere sahip toplumların bireylerinin birlikte yaşama imkânlarını öğrenmeleri ve birlikte yaşamaktan doğan sorunlara çözümler önererek barışa katkıda bulunmayı amaçlayan öğretimdir. Kültürler arası eğitim ile çokkültürlü ${ }^{29}$ (multiculturel) eğitim sıklıkla karıştırılır. Oysa çokkültürlü eğitim, birden fazla kültürün yaşadığ 1 toplumlarda, her topluluğun kendi kültürünü merkeze alarak, diğerlerini de dişarıda tutarak öğretmesi durumudur. Hatta çokkültürlülüğün fazlasıyla kendi kültürü merkezinde (etnosentrik) bir eğitimi öngörmesinin bireysel özgürlük ve tercihlerin önünde aşılamaz bir kısıtlamaya gidebileceği dile getirilmiştir (Aksoy, 2001, s.48; Ensaroğlu, 2001, s.86; Laçiner, 2001, s.157-158).

\footnotetext{
29 Çokkültürlülük modernitenin eşitlikçi, akılcı, evrenselci özellikleri olan felsefî paradigması toplulukların uluslaşma süreçlerinde gerilimler yaratmıştır. Bu gerilim sonunda etnik, dini, mezhepsel farklılıkları taşıyan toplumların kendi kültürlerine odaklanmaları çokkültürlülük düşüncesini yaratmıştır (Aksoy, 2001, s.45). Çokkültürlülük farklı kültürlerin birbirine karışmadan yan yana yaşama hakkının olduğu, daha çok cemaat merkezli bir anlayış olmak yanında farklı kültürlerin karşılıklı etkileşimi üzerine dayanarak bir tür erime potası pratiğini de içerebilir (İnsel, 2001, s.100-101).
} 
Bugün eğitimde kültürün genç kuşaklara hangi boyutlarının aktarılması gerektiği sorusuna; dil, hoşgörü ve empati, doğaya dâhil olma / kendini tanıma, normlar / değerler, topluma uygun tipik davranış örnekleri, düşünme yapısı, teknoloji, ekonomi, spor ve oyunlar, bayramlar ve tatiller, din (Ültanır, 2003) cevabı verilmiştir. Bu tespitte dikkat çekici olan; dil, hoşgörü ve empati, teknoloji, ekonomi, spor ve oyunlar, bayramlar ve tatiller gibi değerlerin uluslar ve toplumlar arası niteliğe sahip olmasıdır. Eğitime yüklenen çağdaş değer ve yaklaşımlarla ilişkili sayılan bu durum kültürler arası eğitim için de bir firsat yaratmaktadır.

Günümüzde kitle iletişim araçları ve uluslararası seyahatlerin artan yoğunluğu dolayısıyla toplumların yaşadıkları coğrafya ve etkili oldukları kültürel sınırlar öğrenme faaliyeti açısından engelleyici ve belirleyici olmaktan çıkmıştır. Küreselleşen dünyada yeniden yapılanan eğitim, bireylere sosyal bir beceri olarak birlikte yaşamayı öğretmeyi özellikle amaçlamaktadır. Çünkü toplumsal anlamda biz-merkezli kültür anlayışından, çok merkezli kültür anlayışına doğru bir evrimin söz konusu olduğu söylenebilir (Uludağ, 2007, s.62). İnsanlar artık çevrelerinin ve yaşadıkları toplumların sınırlarını aşmış, bu da başka kültürleri tanıma ve daha da önemlisi kendi kültürünün yanında diğer kültürü ve/veya kültürleri benimseme, yaşama zorunluluğunu beraberinde getirmiştir. Kısacası bu çağın bireyi kendi kültürünün ve toplum yaşantısının d1şındaki gelişmelerden habersiz olmak anlamında tabiri caizse "taşralı" ve "içe kapanık” olma (Genç ve Eryaman, 2007, s.96) lüksünü çoktan kaybetmiştir. Eğitimle, değişimci ve barışçıl bir dünya yaratmak için ortak tutkuları olan, dünyaya açık, kendine güvenen, toplumsal eşitliği savunarak kültürel ve tinsel zenginliğe önem veren bireylerin yetişmesi gündemdedir. Bu doğrultuda okulun ve öğretmenin işlevi de değişmiştir. Eğitimin yaygın olarak okullarda verildiği göz önüne alındığında bu değişimin kaçınılmaz olduğu fark edilir. Bugün her ne kadar eğitim, okul 
dışına taşınmışsa da bu kez de güvenilir bilgiye ulaşabilmenin önünde başka engeller belirmiştir. Bunlardan en önemlisi olarak "Hangi bilgi önemsenmeli?", "Hangi bilgi doğru?" sorularına verilecek cevabın yine okullarda sunulan eğitim ve bu eğitimin denetiminden geçmesi okula ilişkin düzenlemeleri daha da önemli hâle getirmiştir. Çünkü günümüzde okulun işlevi, bireyleri daha çağdaş ve birlikte yaşanabilir bir toplum için bilinçlendirerek seçici olmalarını sağlamak; bilgiye ulaşma ve kullanma yollarını daha sistemli hâle getirmektir (Balay, 2004, s.69). Bunun için de eğitimle;

- Kültür önkoşullu streotiplerin aşılması,

- Kültürler arası açık bir diyaloğa giriş,

- Başkalarından deneyim kazanmak suretiyle ben-kimliğinin gelişimi,

- Karşıt anlayışların uyandırılması,

- Kültürel değişimlerle zenginleşme amaçlanmıştır (Rey'den akt. Ültanır, 2003).

$\mathrm{Bu}$ durum karşısında öğretmenlerden beklentiler de değişiklik göstermiştir. Öğretmenler artık bilgilerini sürekli yenilemek zorunda kalmışlardır. Öğrenmenin sadece okulda gerçekleşmediği tespitinden hareketle öğrenciler ile aynı dili konuşabilmek adına sürekli bir gelişim içinde olmaları gerekmiştir.

\section{Kültürrler Arası Yaklaşımın Eğitime Yansımaları}

Yukarıda bahsedildiği gibi, dünyada sınırların farklılaşması ve ülkelerin siyasal değişimleriyle başlayan süreçte mevcut ve muhtemel eğitim problemlerini çözmek amacıyla ülkeler yeni müfredatlar oluşturmak zorunda kalmışlardır. Bu müfredatların ortak özelliği; kültürler arası etkileşimi eskisinden daha çok dikkate almak zorunda kalması, 
evrensel değerleri (barış, girişimcilik vs.) önemsemesidir. Bu ortak noktalar ülkeden ülkeye de farklılıklar göstermiştir. Çünkü bazı ülkelerdeki etnik, dinsel ve mezhepsel ayrılıkların derinleşmesi ulusal ve uluslararası kültürel diyaloğun arttırılmasını zorunlu kılmıştır. Bazı ülkeler imparatorluk bakiyesine sahip İngiltere'de olduğu gibi demokratik hak ve özgürlükler çerçevesinde dinsel, mezhepsel ve etnik temelli kültürel eğitime daha fazla izin verilirken, uluslaşmanın öncülerinden Fransa gibi bazı ülkeler ise yurttaşlık tanımını daha sert dile getirmiştir. ${ }^{30} \mathrm{Bu}$ durum devletlerin kültürler arası (interculturel) ve/veya çokkültürlü (multiculturel) eğilimlere tepkilerini de farklılaştırmıştır. Ülkelerin toplumsal ve siyasal yapılarından hareketle farklı öncelikler verdiği eğitimde kültürler arası durum eğitimcilerce tartışılmaya, yeni açılımlar sunulmaya devam edilmiştir. ${ }^{31}$ Örneğin bunlardan Trassberg, Asser ve Vassilcheko (2004, s. 34) günümüz dünyasının okullaşmasını 7 ana sınıfa ayırmıştır. Bunlar:

- Tek kültürlü toplumlarda tek kültürlü okullaşma

- Tek kültürlü toplumlarda iki kültürlü okullaşma

- Tek kültürlü toplumlarda çok kültürlü okullaşma

- $\quad$ İki kültürlü toplumlarda iki kültürlü okullaşma

- Çok kültürlü toplumlarda iki kültürlü okullaşma

- Çok kültürlü toplumlarda çok kültürlü okullaşma

- Uluslararası okullaşmadır.

Ülkeler eğitim alanında yaptıkları değişiklikler ile yukarıdaki

30 2000'li yılların ortalarında Fransa'nın resmî ağızlardan “Fransa'da azınlık yoktur, Fransa'da yaşayan herkes Fransız vatandaşıdır" yaklaşımı bu çerçevede anılabilir.

31 Özellikle Anglo-Sakson dünyasının ve kuzey ülkeleri olan Nordik (Norveç, İsveç, Danimarka, Finlandiya), Benellüks (Belçika, Hollanda, Lüksemburg) ve Baltık (Litvanya, Letonya, Estonya) gibi coğrafyalarında birden çok etnik ve dinî topluluğun yaşadığı toplumlarda ön plana çıkan çokkültürlülük (birden çok kültüre aynı anda sahip olarak çok kimlikli bireyler) mevzubahis görünmektedir. Buna karşın yukarıda da belirtildiği gibi Fransa benzeri ulusal kimliği ve vatandaşlık tanımında daha sert olan Güney Akdeniz ülkelerinin (buna Türkiye'de dâhildir) vatandaşlık tanımlarında çokkültürlülüğe sıcak bakmadıklarını burada belirtmekte yarar vardir. 
sınıflandırmanın farklı basamaklarında okul sistemlerine sahip olmaktadırlar. Uluslaşmanın sert biçimde kendini sürdürdüğü ülkelerin tek kültürlü bir yapıya sahip oldukları iddiaları, tek kültürlü okulu tercih etmelerini beraberinde getirirken, çok kültürlü yapıya sahip ülkelerin okullaşması da elbette ki farklılaşmaktadır. Birden fazla kültürel yapıyı ve kimliği (alt-üst) yapısında barındıran toplumlar ise kaçınılmaz olarak bu durumu eğitimlerine yansıtmaktadır. Bunlar "iki kültürlü okullaşma", "çokkültürlü okullaşma" ve "uluslararası okullaşma" kategorilerine dâhil olmaktadir.

\section{Dünyadan Kültürler Arası Eğitime Örnekler}

Kültürler arası eğitim planlama ve uygulamaları bağlamında dünyadan Bulgaristan, Yunanistan, Estonya, Finlandiya, İsveç, Hırvatistan ve Norveç ülkeleri ile bir uluslarüstü yapı olan AB'nin yaptığı çalışmalara ilişkin örnekler fikir verici olacaktır:

Bulgaristan'da kültürler arası eğitim için dört boyutta çalışmanın yapıldığ1 görülmüştür. Bunlardan ilki ülkede yaşayan Hristiyan ve Müslümanlar arasındaki anlayışı arttırma için okullarda dinler arası eğitimi arttırmaya çalışılmasıdır. Bununla çok etnikli ve kültürler arası öğrenme deneyimlerini geliştirme için kültürler arası etkileşimi gerçekleştirme amaçlanmıştır. Bulgar ders kitaplarında kültürler arası eğitim ve vatandaşlık eğitimi vasıtasıyla yabancılaşma ve ayrımcılık konularını ele alma konusunda çalışmalar yapılmıştır. Son olarak da kültürler arası eğitimi ve dil öğretimi ve özellikle Avrupa'da dil öğretimi teşvik edilmiştir (Davcheva ve Milena, 2006).

Yunanistan'da ise 1996 yılında çıkarılan ve 11 maddeden oluşan kanunun bir maddesi kültürler arası eğitimi önemsemiştir. Bu kanun ile çok kültürlü sınıflar konusunda çalışmalara başlanmıştır (Paleologou, 2004). Yunanistan'da 2008 yılında yaşanan tarih ders kitaplarında yer alan “Küçük Asya Bozgunu” (Millî Mücadele) konusundaki Türk 
düşmanlığını kaldırmak için yapılan çalışmaların aldığı büyük tepkiyle eğitim bakanının istifa etmek zorunda kalması, bu ülkede kültürler arası çalışmaların kolaylıkla yürütülemediğini de göstermiştir.

Estonya'da kültürler arası eğitim ile ilgili olarak yapılan çalışmalar, ülkenin bağımsızlığını kazanmasından sonraya denk gelir. 1996 yılında Estonya Okulları için bir müfredat hazırlanmıştır. Bu müfredatın amacı Estonya ulusuna ve kültürüne dikkat çekmektir. Müfredatın içeriği ülkenin kültürünü ilerletmek ve yaşatmak kadar ülkede yaşayan etnik azınlıkların kültürel kimliklerini desteklemek, aynı zamanda öğrenme aktivitelerini organize etmek ve tüm bireylerin farklı yetenekleri ve öğrenme gereksinimleri olduğunu dikkate almaktır (Asser, Trassberg ve Vassilchenko, 2004).

Finlandiya müfredatı ise 1997'de revize edilmiştir. Buna göre öğrenciler insanların farklı olduğunu, farklı kültürleri taşıdığını, insanların ve ulusların dayanışmasının ve eşitliğin insani değerlerin temelini oluşturduğunu bilirler. Sorunlara karşı farklı çözümlerde bulunmak, karşılıklı etkileşim, diğer kültürleri bilme, temel kültürel okur-yazarlık, küresel vatandaşlığa hazır olma, uluslararası gelişmeleri takip etme önceliklidir (Asser, Trassberg ve Vassilchenko, 2004).

İsveç’te oluşturulan müfredata göre uluslararası bakış açısı önemlidir. Amaç, başkasının gerçekliğini görmek, küresel dünyada ve uluslararası alanda dayanışmayı sağlamaktır. Öğretmenler tüm öğrencilerin cinsiyet, sosyal durum ve kültürel geçmişinin çalışma metotlarını ve eğitim içeriğini etkilediğinin farkında olmalıdır. Finlandiya, İsveç ve Norveç müfredatlarının ortak noktası; kültürler arası, çok kültürlü ve uluslararası eğitimi, kültürel kimliği, anadili ve azınlık dillerini, özel eğitimi, dinleri (Protestan-Luteriyan, Ortodoks ve diğerleri), cinsiyet eşitliğini vurgulamasıdır (Asser, Trassberg ve Vassilchenko, 2004).

Hırvatistan'da 1994-1998 arası gerçekleştirilen kültürler arası eği- 
time ilişkin iki proje Roman vatandaşlara yönelik olmuştur. İlk olarak Hırvatistan'daki "Roman Çocuklar İçin Yaz Okulu Projesi” ve "Roman Eğitimi Topluluğu” kurulmuştur. Hırvatistan'daki "Roman Çocuklar İçin Yaz Okulu Projesi”, Romanlar için yapılan ilk program olma özelliğini taşır. Amaç Romanların ulusal kimliğinin (tarihi, kültürü, gelenekleri, dili ve lehçeleri) korunmasıdır. "Roman Eğitim Topluluğu" ise kültürler arası din ve eğitim hakkındadır (Posavec ve Hrvatic, 2000).

Diğer bir uygulama ise uluslarüstü bir organizasyon olarak Avrupa Birliği tarafından 1987 yılından itibaren yükseköğretim kurumlarında okuyan öğrenci ve öğretim görevlilerine yönelik uygulanan Erasmus programıdır (web 1). Bununla öğrenci değişimi yapılmakta ve bu öğrenciler farklı kültürlerin içinde yaşayarak o kültürleri tanımaktadırlar. Avrupa Birliği Eğitim Programları, farklı kültürlerden gelen gençlerin diyalog yoluyla kaynaşmasını sağlayarak, saygı, hoşgörü ve anlayış bilincinin oluşturulması ve geliştirilmesine destek olmaktadır (Demir ve Demir, 2009, s.95).

Avrupa Birliğì'nin öğrenci değişimine ve kültürler arası etkileşime yönelik bir diğer uygulaması ise okul öncesi, ilköğretim ve ortaöğretim öğrencilerine yönelik olarak uyguladığ 1 Comenius programıdır. Bu program ile amaçlanan ise “'Okul Eğitimi” alanında Avrupa ülkeleriyle iş birliği yapmak suretiyle eğitimde kaliteyi artırmak ve kültürel diyaloğu sağlayarak dil öğrenimini teşvik etmektir”'(web 2).

Türkiye'de de öğrenciler Avrupa Birliği tarafından gerçekleştirilen yukarıdaki projelere katılmaktadır. Aynı zamanda Türkiye'de kültürler arası eğitimi yaygınlaştırmak amacıyla kullanılan 3 eğitim programı daha vardır. Bunlardan ilki IB (International Baccalaureate) Diploma Programı'dır. Merkezi Cenevre'de bulunan bu programın 139 ülkenin okulları ile anlaşması vardır. Türkiye'de 27 okul ile anlaşması bulunan programın amacı ise gençlerin kültürler arası anlayış ve saygı yoluyla 
daha barışçıl ve iyi bir dünya kurmalarına yardım etmektir. Program öğrencilerine hayat boyu öğrenmeye katkı olacak şekilde kendilerinden farklı insanların olduğunun farkında olmalarını beklemektedir (web 3).

Diğer program ise ABD Kent State Üniversitesi ile birlikte yürütülenidir. Amerikan eğitim siteminin desteği ile öğrencilerine çağdaş bir eğitim sunmak, yapılandırmacı eğitim aracılığıyla, yaşam boyu öğrenen ve öğrendiğini uygulayan, evrensel olma bilinci taşıyan ve evrensel değerlere açık dünya vatandaşı olan, özgüvenli ve yaratıcı bireyler yetiştirmektir (web 4).

$\mathrm{Bu}$ araştırmanın temelini oluşturan Kanada Lisesi Diploma Programı (Kanada Programı) okyanus aşırı ülkelerde Kanada Manitoba Eyaleti'nin eğitim programını uygulamaktadır. Türkiye dışında bu programı uygulayan Misır - Heritage International School; Gana - Canadian Independent College Of Ghana; Japonya - Meitoku Gijuku School; Çin Halk Cumhuriyeti - Clifford School (Clifford Experimental School); Tayland - Lertlah School (web 3) öğrencileri de Kanada diploması almaktadırlar.

\section{Kültürler Arası Bir Eğitim İmkânı Olarak Kanada Programı}

Kanada Programı gereğince öğrenciler hazırlık +4 yıl boyunca, başta yoğunlaştırılmış İngilizce görürler. Dersler; Social Studies (Sosyal Bilgiler), Physical Education (Beden Eğitimi) / Health (Sağlık), Science (Fen Bilgisi), Maths (Matematik) ve Art (Resim) olarak belirlenmiştir. Adı geçen dersleri, yapılan sözleşme gereğince sadece Kanada vatandaşı olan ve Kanada'daki üniversitelerden mezun olan öğretmenler verebilir.

Kanada Programı öğrencileri MEB'in müfredatında bulunan (Tarih, Coğrafya, Türk Edebiyatı, Dil ve Anlatım, T.C. İnkılâp Tarihi ve Atatürkçülük, Din Kültürü ve Ahlak Bilgisi, Felsefe) dersleri almakta, diğer dersleri ise (Matematik, Fizik, Kimya, Biyoloji, İngilizce, Tarih, 
Coğrafya, Beden Eğitimi ve Resim) Kanada Okul Programı'nın müfredatına göre işlemektedirler. Program gereğince iki programın da dersleri birbirine entegre edilmiştir.

Kanada Programı ders kitapları Kanada'dan gönderilmekte ve Manitoba Eyaleti'nde öğrenim gören öğrenciler ile aynı zamanda aynı konular işlenmektedir. MEB tarafından belirlenmiş olan ölçme-değerlendirme sisteminden farklı olarak, yapılan sınavlar bütünün sadece \% 15'ini oluşturmaktadır. \% 85'lik pay ise projeler, ödevler (sınıf içi ve ev ödevleri), derse katılım, devam-devamsızlık ve ders içi disiplin tarafından oluşturulmuştur. Öğrenciler hazırlık sınıfında 3 kredi olmak üzere, 9, 10, 11, 12. sinıflarda minimum 30 kredi almak zorundadırlar. Manitoba Eyaleti tarafından önerilen ve öğrencilerin sıklıkla başvurdukları “Kanada'da Yaz Okulu” uygulamasında ise, öğrenciler üniversitede hangi alanda eğitim görmek istiyorlarsa, o eğitimin hazırlık sınıfına devam etmektedirler. Mesela tıp okumak isteyen bir öğrenci Kanada'da 2 ay süresince Anatomi dersi görebilir ve bu dersten edindiği krediyi Türkiye’ye döndüğünde okul kredisine ekleyebilir.

$\mathrm{Bu}$ programı bitiren öğrenciler bir Kanada vatandaşının eğitim alanında sahip olduğu tüm haklardan yararlanabilirler. Üniversite başvurularında SAT ve TOEFL (Yabancı dil yeterlilik sınavı) belgesinin ibraz edilmesine gerek yoktur. Kanada devlet üniversitelerine doğrudan başvuruda bulunabilirler ve barınma, burs, kitap gibi yardımları almaya hak kazanırlar.

\section{Yöntem}

\section{Araştırmanın Deseni}

Araştırmada, nitel araştırma desenlerinden olgubilim (fenomenoloji) deseni kullanılmıştır. Olgubilim çalışmalarında genellikle belli bir 
olguya ilişkin bireysel algıların veya perspektiflerin ortaya çıkarılması ve yorumlanması amaçlanır (Yıldırım ve Şimşek, 2006).

\section{Araştırma Grubu}

Araştırma grubunu, İstanbul ili sınırları içerisinde bulunan ve öğrencilerine Kanada Lisesi Diploması veren bir özel okulun 9, 10, 11 ve 12. sınıfından 4-6'şar olmak üzere 9 kız ve 10 erkek toplam 19 öğrenci oluşturmaktadır.

$\mathrm{Bu}$ çalışmada veri toplama olarak yapılandırılmış görüşme tekniği kullanılmıştır (Yıldırım ve Şimşek, 2006, s.95). Konu temelli bir görüşme yolu tercih edilmiş, yorumlayıcı araştırmacı görüşülenlerin deneyimlerini ve bakış açılarını anlamak için empatik bir anlayışla görüşmeyi tamamlamıştır (Kuş, 2007, s.91). Görüşme formunda toplam 9 soru yer almıştır. Bu sorular ve her birine verilen cevaplar bulgularda sunulmuştur. Araştırmacılar tarafından görüşme kriterleri belirlendikten sonra araştırmacılardan biri tarafından öğrenciler ile görüşülmeye başlanmış ve görüşmelerin her biri 20-25 dakika aralığında gerçekleşmiştir. Görüşmeler toplamda 3 hafta içinde tamamlanmıştır. Öğrencilere görüşme öncesinde proje içeriğinden ve araştırmanın hangi amaçla yapıldı̆̆ından bahsedilmiş, görüşmede sağl1klı veri toplamak için samimi bir ortam yaratılmaya çalışılmıştır. Aynı zamanda görüşme yapmak için -okulun kısıtlı fiziki şartlarından dolayı- sessiz ve kimsenin rahatsız edemeyeceği bir ortam sağlanmaya çalışılmıştır.

Görüşmeler araştırmacı tarafından kameraya kaydedilmiş ve daha sonra yazıya aktarılmıştır. Araştırmada görüşme yolu ile elde edilen veriler betimsel analiz yöntemi ile çözümlenmiş ve yorumlanmıştır. Betimsel analiz, elde edilen verilerin daha önceden belirlenen temalara göre özetlenmesi ve yorumlanmasıdır. Betimsel analizde, görüşülen ya da gözlenen bireylerin görüşlerini çarpıcı bir biçimde yansıtmak amacıyla doğrudan alıntılara sık sık yer verilir (Yıldırım ve Şimşek, 2006, s.158- 
159). Araştırmaya katılan öğrenciler Ö1, Ö2.. şeklinde kodlanmışlar, bulgular da bu kodlara göre yazılmışlardır. Öğrenci görüşleri metin içinde italik olarak yer almaktadır.

\section{Bulgular ve Yorum}

\section{Bulgu 1. Öğrencilerin Kanada Programı tarih dersleri hakkında- ki genel düşünceleri}

Kanada Programı'ndaki öğrencilerin geneli tarih öğretimiyle ilgili olumlu görüş bildirmiş̧tir. Kanada Programı tarih dersleri; kolay, güzel, eğlenceli, iyi, neşeli biçimlerinde görüşler (Ö1, Ö4, Ö7, Ö8, Ö11, Ö19 Ö18, Ö14) dile getirilmiş, bunun yanında hem tarih hem coğrafya eğitiminin birleşik yapılması olumlu bulunmuştur. Örneğin bunlardan Ö18, “Çok başarılı buluyorum. Çünkü bu dersler öğrencinin araştırmasına bă̆ll, ögretmen konuyu ana hatları ile anlatıp bizim araştırmamızı bekliyor. Çok ögretici bu." diyerek derslerin araştırma temelli işlendiğini, bunu da olumlu bulduğunu ifade etmiştir. Ö8 ise "Hem tarih hem coğrafya hem de dünyanın genel pozisyonunu görüyoruz. Ders çok neşeli ve iyi, çok sevdiğim, çok güzel bir ders" diyerek gerçekleştirilen interdisipliner öğrenmeye dikkat çekmiştir. Aynı sınıftan Ö9 ise "Kanada tarihini görüyoruz. Tek Kanada değil dünya tarihini de içine alıyor" diyerek Kanada tarih öğretiminin dünya tarihi çerçevesinde ele alındığını belirtmiştir.

Ö16 ise konunun başka bir yönüne dikkat çekerek, “Kolay, Türkler kadar tarihleri olmadiğı için işledikleri konu 1. ve 2. Dünya Savaşları. Bu savaşlarda kaybettikleri askerler için yapılan törenleri onların ne kadar değerli olduklarını ve onun benzerinde ne kadar çok asker kaybettiklerini belirten bir yol izlemeye çalışlyorlar, ama Osmanl gibi geçmiş tarihleri yok, o yüzden de tarihleri daha kolay.” demiştir.

Buna karşın öğrencilerin bir kısmı (Ö3, Ö6, Ö10, Ö17) ise zor, kat- 
kıs1 az, yeterli değil, memnun değilim diyerek olumsuz değerlendirmede bulunmuşlardır. Bunlardan Ö10 “Bu yıl coğrafya görüyoruz. Geçen yıl genel kültür düzeyindeydi. Bu yıl memnun değilim." Ö17 ise "Yeteri kadar işlemiyoruz. Daha fazla bilgi edinmeliyiz." demiştir.

\section{Bulgu 2. Öğrencilere göre Kanada ve Türk Programları tarih dersleri arasındaki farklar ve benzerlikler}

Kanada ve Türk Programlarında tarih derslerinin farkını ele alan öğrencilerin bir kısmı (Ö6, Ö16, Ö17, Ö7), Kanada Programıyla Türk Programı arasında önemli farkların bulunduğunu, Türk tarihinin çok eski dönemlerden bugüne kadar uzun bir zamanı kapsamasına rağmen, Kanada'nın kuruluşunun çok eski olmaması nedeniyle tarihinin de kısa olduğu vurgusunu dile getirmişlerdir. Örneğin Ö6 "Türk tarihi çok geniş, işlenecek çok daha fazla şey var. Öğrenip ders çıkarılması gereken çok fazla şey var. Ama Kanada tarihi çok sı̆̆ olduğu için hokeyi bile bir madde olarak tarih kitaplarında tarih olarak alabiliyorlar" demiştir. Ö17 ise bunu öğrenme açısından bir avantaj olarak görmüş, "Bizimki zor, onlarınki kolay ve daha anlamlı.” diyerek değerlendirmiştir. Ö7 ise "Türk tarihi insanlı̆̆ın eskisine dayanıyor. Avrupa'yı Orta Asya'yı çölleri kapsıyor. Kanada programı ise Kanada'nın bulunuşu ve Sanayi Devrimi'nden sonrasinı kapsar. İkisi de dünyayı etkileyen olaylara (1 ve 2. Dünya Savaşı) yer veriyor" diyerek eskilik bakımından farklarına yer verirken yakınçağda dünyayı etkileyen olaylara yer vermeleri bakımından benzer bulmuştur.

Öğrencilerden bazıları da Kanada Programının daha evrensel (dünya ile ilgili), daha çok araştırmaya dayandığını belirtmiştir. Örneğin $O ̈ 9$ "Kanada Programı daha evrensel baklyor, daha objektif. İkisi de kendi ülkesini işliyor ama çok benzer olduğunu düşünmüyorum” diyerek Kanada tarih programının objektif bakış açısına dikkat çekmiştir. Ö18 ise “Türk Programında tarih dersi ezbere dayanıyor. Bu ögrretmene göre 
değisşiyor ama. Kanada araştırmaya dayal, nasıl araştırma yapılır, nasıl sunum hazırlanır, toplum içinde nasil konuşulur öğretiyor" demiştir.

Kanada Programında tarih öğretimi Social Studies adı ile bilinen Sosyal Bilgiler içinde yapıldığg için bazı öğrenciler coğrafya, kültür, nüfus, toplum gibi konuların öğretilmesini de iki program arasında bir fark olarak dile getirmiştir. (Ö1, Ö4, Ö8, Ö10) bunu vurgulamışlardır. Ö11 ise "Kanada programında tarih öğrenmiyoruz, sadece sosyal öğreniyoruz." diyerek konuya açıklık getirmiştir.

Kanada Programı ile Türk Programında yer alan tarih derslerinin benzerleri sorulduğunda ise öğrencilerin çoğunluğu önemli benzerlikler olmadığ görüşünde birleşmiştir. Bunun yanında (Ö6, Ö12, Ö15, Ö14, Ö16, Ö17) sadece devlet, siyaset, savaşlar, önemli tarihler konularının her iki programda da yer bulduğunu söylemişlerdir.

\section{Bulgu 3. Kanada Programındaki Social Studies (Sosyal Bilgiler) dersinin içeriği hakkında öğrencilerin farkındalıkları}

Öğrencilerin Kanada Programı tarih derslerinde öğrendiklerinin belli başlı konularda yoğunlaştığı görülür. Bunlar;

İçerik olarak ilk sırada “Kanada tarihi” (Ö3, Ö6, Ö12, Ö8 Ö14, Ö18) denmiştir. Bunlardan Ö18 "Genelde Kanada tarihi kapsaml olmasa da diğer ülkelerin tarihini de öğreniyoruz.” diyerek tarih eğitiminin Kanada ile ilişkili diğer ülkelerin tarihleriyle birlikte verildiğini söylemiştir. Ö19 ve $O ̈ 17$ ise derslerde genel dünya durumuna değinildiğini belirtmiştir.

İkinci surada Kanada coğrafyası (Ö6, Ö8, Ö9, Ö10, Ö13, Ö7) konu başlığı vardır. Bunlardan $O ̈ 7$ “Kanada'nın demografik konuların işliyoruz. (yemek nereden gelir, endüstri türleri...)" diyerek öğretimin yönüne ilişkin de bilgi vermiştir.

Üçüncü sırada Kanada'da genel seçimler, demokrasi, insan hakları, ülke kanunları, gelenekler, devlet törenleri (Ö1, Ö4, Ö3, Ö10, Ö9) 
konuları yer almıştır.

Dördüncü sırada Kanadalı liderler, bakanlıklar, devletin işleyişi (Ö4, Ö6, Ö11) konusu bulunmaktadır.

Beşinci sırada "HSBC bombası", "Moskova'da terörizm”, "Londra Metrosu'nun bombalanması” gibi terörist saldırılar konusu $(\ddot{O} 16, \ddot{O} 19)$ vardir.

İçeriğin dişında ders işleniş tarzı olarak sosyal proje, (Ö10, Ö19) yaklaşımı bir fark olarak değerlendirilmiştir. Bunlardan Ö10, "Sosyal projemiz vardı: Ăgaçlı Köyü Okul Projesi. Fiziksel yapısını değiştirmeye çalıştık. Sonunda ödev vardı." demiştir. Ö19 ise "Sonra herkes saha önce olan bir terörizm konusunu yaptı." diyerek proje temelli ders işlendiğini belirtmiştir. Ö10'un verdiği cevaptan anlaşıldığı üzere Kanada programında derslerin öğrencilerin daha aktif olarak katılacağı ve yaşamla ilişkili şekilde yapılandığı söylenebilir.

Başka bir öğretim farklılığı olarak da Ö16 tarafından “Geçmiş olayları 1900'lerde olanları günümüzdekilerle karşılaştırma" dile getirilmiştir. Ö16 bununla tarih derslerinde dönemsel karşılaştırmaların yapıldığını bildirmiştir.

Kanada Lisesi Diploma Programı'nda tarih derslerini işleme biçiminin öğrenciler tarafından farklı bulunduğu söylenebilir. Bunun nedeninin derslerin proje temelli, öğrenci merkezli ve araştırmaya yönelik olarak işlenmesi olduğu düşünülmektedir. Bugün yapılandırmacı yaklaşımın gereklerinden biri olarak görülen proje tabanlı öğrenmeyle öğrencilerin aktif olmayı, sorgulamayı ve araştırmayı kavramaları daha mümkün hâle gelebilmektedir (Koca ve Şimşek, 2010) Üstelik öğrencilerin ders görevi olarak farklı bir kültürün değerlerine yönelik yapılan araştırmalar, belli ki o kültüre daha çok yakınlaştırmakta ve yabancılık problemini ortadan kaldırmaktadır. 


\section{Bulgu 4. Öğrencilerin Kanada Programı'nda çağdaş dünya tarihinin yeri ve öğretimin tarafsızlığına ilişkin görüşleri}

Öğrencilerin büyük bir çoğunluğu (Ö1, Ö4, Ö7, Ö8, Ö19, Ö18, Ö12, Ö13) Kanada Programında çağdaş tarih konularına yer verildiğini, öğretimin de tarafsız olduğunu belirtmiştir. Örneğin bunlardan $O ̈ 1$ “Bunlarla ilgili bilgi var. Tarafslzlar ne varsa anlatıyorlar” demiştir. Ö19 "Veriliyor gibi. Geçen sene daha yoğundu. Bu sene daha spesifik. Geçen sene Kanada'ya (tarihine) yoğunlaşmıştık, bu sene dünya tarihi yapıyoruz. Başka bir ülke hakkında yorum yaparak ders işlemiyoruz. Genelde Kanada'yı işliyoruz. Biz de Türk - Kürt çatışması var, onlarda da Kanada - Quebec çatışması var. Bazen onlar hakkında taraf yapabiliyorlar ama onlar (bunun) dışında yok." demiştir. Ö18 ise "Evet daha fazla. World Issues'da güncel konular işleniyor. Medya, coğrafya terörizm. Evet tarafsızlar. Etik olarak ögretmen taraf tutmuyor. Sunumu taraflı yapamıyoruz." demiştir. Ö12 ise "Tarafsızlar. Tamamen Kanada'yı korumuyor, kim kazandıysa onu anlatıyor." demiştir.

Bazı öğrenciler $(O ̈ 16, O ̈ 17)$ ise bunun öğretmene göre değiştiğini belirtmişlerdir. Bunlardan Ö16 "Çok fazla değil, onlar daha rahatlar, okulda politika üzerine konuşuluyor. Siyasi partiler hakkında konuşuluyor, her ikisine de aynı pencereden bakllyyor. Ortada tartışma ve ortak fikrini ortaya koyduğun bir durum oluyor. Bizde ise daha farkl, politika yasak, 2 partiyi karşılaştıramıyoruz. Tarafsızlık ise bazı okullarda evet, bazı okullarda hayır. Bölgeye, ögretmene göre değişiyor.” demiştir. Bu durum Demircioğlu ve Tokdemir'in tespitleri ile paralellik göstermektedir. Buna göre kültürler arası eğitim ile kendi kültürünün eğitiminin yanında diğer bir kültür ile de tanışan öğrenci, tarih dersinin gereklerinden biri olan "çok yönlü düşünebilmeyi” (Demircioğlu ve Tokdemir, 2008) iki kültürün "kültürü” ile işlediklerinde dünyaya ve olaylara bakış açısının değişmesi söz konusu olmaktadır. 
Bazı öğrenciler ise konuya ilişkin bilgi sahibi olmadığını (Ö3, Ö6, Ö10, Ö9, Ö11) söylemiştir.

\section{Bulgu 5. Öğrencilerin Kanada Programı tarih derslerinde diğer toplumların uygarlığa katkılarına yeterince yer verilip verilmediğine ilişkin görüşleri}

Kanada Programı tarih derslerinde diğer ülkeleri ele alma durumuna ilişkin öğrenci (Ö16, Ö1, Ö4, Ö5, Ö7, Ö8, Ö19, Ö11, Ö18, Ö14) görüşlerine göre diğer ülkelere yeterince yer verilmediği gibi verilen yer de Kanada tarihiyle ilişkisi bağlamında kalmaktadır. Genel olarak öğrenciler bu durumu yeterli bulmamaktadır. Bunlardan Ö6 "İngiltere’nin Kanada' da yaptı̆̆ı sömürge ile ilgili bir şeyler gördük. Bir bakıma görüyoruz, ama yeterince ele alındığını söyleyemem.” demiştir. Ö7 ise "Hayır. Diğer uygarlıklara değinilmedi. Kanada tarihi boyunca. Çünkü Kanada tarihi yakın tarihe bağll, uzak tarihle işi yok. Diğer ülkelere o kadar önem vermiyor" demiştir.

Bir de konuyla ilgili bilgisiz olanlar vardır (Ö3, Ö11, Ö18, Ö14, Ö10). Bunların bir kısmı Social Studies (Sosyal Bilgiler) dersi kapsamında o zamana kadar coğrafya ve sosyal konuları gördüklerini, tarih görmeye henüz başlamadıklarını belirtmişlerdir. Örneğin Ö9, "Gösteriliyordur galiba. Geçen sene timeline'da (tarih şeridi) yaptık detaylı olmasa da konuya değindik." diyerek durumu özetlemiştir.

\section{Bulgu 6. Kanada Programı'nda tarih derslerinin barışçı bir dünya tasarımına hizmet edip etmediğine ilişkin görüşleri}

Kanada Programı'nda okuyan öğrencilerin tarih derslerinin barışçı bir dünya tasarımına hizmet edip etmediğine ilişkin düşünceleri incelendiğinde öğrencilerin biri hariç hepsi programın barışçıl bir tarafının olduğunu söylemiştir. Bunu kimi öğrenci farklı problemlere aranan barışçı çözümler ile (Ö16, Ö7, Ö8, Ö17), kimi programının konuyu ele alış 
şekli ile (Ö1, $\ddot{O} 4, \ddot{O} 3, \ddot{O} 7, \ddot{O} 9)$, kimi savaşa karşı ülkenin tutumu ile (Ö19, Ö14), kimi de konuları tarafsız ele alıs şekli ile (Ö5, Ö18, Ö12, Ö11, Ö13) gerekçelendirmişlerdir. Öğrencilerden sadece $\ddot{O} 10$ " $B u$ yll imkân yok. Geçen yll evet. İnsan hakları konusunda ülke inceleme. Dönem ödevi gibi projemiz var. Barış̧̧l mesajlar veriliyor." diyerek bulunduğu yıldaki dersin programından kaynaklı olarak barışçı yaklaşımın olmayacağını söylemiş ancak bir yıl önce var olduğu ile ilgili ifadede bulunmuştur.

Programın barışçı unsurlar barındırdığını düşünen öğrencilerden, çözüm yolu gerekçesini belirten Ö17 düşüncesini "evet çünkü Kanada United Nations'ı (Birleşmiş Milletler) kuran ülke. UN'de çoğu ülkenin barış̧̧l bir dünya üzerinde yaşama amacı var... Benim geçen sene yaşadlğım tecrübemde bu konular çok ciddi ele alıniyor. Afganistan'daki terörist atakları, Amerika-Irak Savaşı bunlar nasıl barış̧̧ll bir şekilde çözülebilir diye tartışmalar yapıllyor.", Ö8 ise, "Kesinlikle evet. Geçen hafta 'açllk' üzerine bir konu işlemeye başladık, bu açlığın nasıl düzeleceği, nasll çözüm üretebileceğimiz, karşıdaki ülkenin ekonomisine zarar vermeden nasıl çözeceğimiz anlatıldl." şeklinde ifade etmiştir. Öğrenci hem dünyanın en önemli sorunlarından biri olan açlık konusunda çözüm önerileri geliştirmekte, bunu tasarlarken aynı zamanda ekonomiyle de ilgilenmektedir. Genç ve Eryaman’ın da belirttiği gibi öğrenci bu sayede olay hakkında geniş boyutlu düşünebilme yetisini kazanmakta, aynı zamanda problemi çözerken başka alandaki bilgilerini de kullanabilmektedir (Genç ve Eryaman, 2007, s.97).

Programı konuyu ele alış şekliyle değerlendiren öğrencilerden $O \ddot{9}$ "Evet. Genel olarak Türk Programina göre daha dünya endeksli ve daha gelişmiş. Bazı kitaplarda kısa kısa mesajlar veriliyor. Metinde videoda geçebiliyor, öğretmen söyleyebiliyor." demiştir.

Ülkenin savaşa karşı tutumunun programa yansıdığını düşünen öğrencilerden Ö19 "Düşünüyorum. Kanada şu anda barış̧̧ıl bir ülke, 
savaşa girmiyorlar, yardım olayı o zaman gönderiliyorlar”, Ö14 “Evet, çünkü kendi başlarına hiç savaşa katılmamışlar" diyerek durumu gerekçelendirmişlerdir.

Programın tarafsızlığına değinen öğrencilerden Ö5 "Evet çünkü Kanada tarafsız bir ülke. Hiçbir taraf tutmadan yani Ingilizlerin sömürge yaptığını anlatırken bile İngiltere’yi herhangi bir şekilde kötülemiyor. Herhangi bir taraf tutmadan anlatıyor.”, Ö18 "Evet objektif işleniyor ders. Öğrencilere milliyetçilik aşılanmıyor, tamamen objektif." demiştir. Kültürler arası eğitimle amaçlanan bireyleri bir bütün olarak bir arada bulunmasını sağlamak, çatışma yerine barışı sağlamaktır (Küçük, 2011). Bunun için de öğrencilere dar milliyetçi bir anlayış aşılanmaz. Çünkü dar milliyetçilik ile öteki kavramının yaratılması kaçınılmazdır (Nohl, 2009). Oysa kültürler arası eğitimin doğasında var olan bütünlük ve barış ortamı, dar milliyetçiliği yok sayar.

\section{Bulgu 7. Kanada Programı tarih derslerinde kültür ve toplum etki- leşimi konularının varlığına ilişkin görüşleri}

Kanada Programı'nda tarih derslerinde kültür ve toplum etkileşimi konuların varlığgna ilişkin olarak 14 öğrenci var olduğunu söylemiş, 2 öğrenci ise bulunmadığını ifade etmişlerdir. Var olduğunu söyleyen öğrencilerden 11 tanesi ifadelerini örneklendirmiştir. Bu ifadeler incelendiğinde, öğrencilerin "farklı kültürlere yaşam hakkı tanınması (Ö16), toplumların özellikleri (Ö7, Ö9), ele alınan konular (Ö4, Ö18, Ö19), etkileşimin belli ülkeler ile sinırlı olması (Ö4, Ö8, Ö11, Ö12, Ö17, Ö14)" ifadelerinde bulundukları görülmüştür.

Farklı kültürlere yaşam hakkı tanınmasıyla ilgili olarak Ö16 düşüncesini “Tabii ki var. Kanadalı diye bir şey yok. Kanadalı demek doğru değil. Çoğu daha refah bir hayat sürmek için Kanada'ya yerleşmiş, orada her türlü insan var, bu da Kanada'nın tek ülke olmasını şu bakımdan sağllyor... Yaz aylarında Türk festivali var. Dövme festivali, Afrika'nın 
festivalleri yapılıyor.” şeklinde ifade etmiştir. Bu görüş, Kanada'nın içinde barındırdığı toplumlara verdiği özgürlüğü ifade etmektedir. Sonuçta Bolovan'ın (2009) da belirttiği gibi, bir üst kimlik olarak Avrupa vatandaşı olmanın kişinin kendi kimliğini ve kültürel kimliğini veya geleneksel ve dinsel inancını kaybetmesi anlamına gelmemesi gibi Kanadalı olmak da ulusal bir kimliğe karşılık gelmemektedir.

Toplumların özellikleri ile ilgili olarak Ö9 "Kanada programında kültür çok önemli. Toplumları inceleyebiliyoruz. Sosyal sorumluluk projeleri yapıyoruz" demiştir. Ele alınan konular olarak Ö4 “Onlarda kurallar önemli ve nasıl davranılması gerektiği önemli. Onun için kitaplarda konu olarak işleniyor" ve Ö19 "En çok onu işliyoruz. Mesela sinıfta herkese kültürel bir konu veriliyor, mesela savaş. Sonra öğretmen örnekler veriyor, sonra herkese bir savaş veriyor, ögrenci sunum hazırlayıp sorular çıkartıyor. Öğretmen o soruları kabul ederse onları kullanıp sınav yapıyorlar" demiştir.

Etkileşimin olduğunu ancak belli ülkelerle olduğunu söyleyen öğrencilerden Ö17 düşüncesini “Kanada kültürüne yanslyan olaylar yansitıllyor. Fransa ve Ingiltere'nin Kanada'ya gelmesiyle oluşan kültürü yansitıyor" şeklinde, Ö8 “Amerika ve Ingiltere var ama diğer dünya ülkeleri ile yok" şeklinde ifade etmiştir.

Programda etkileşimin olmadığını söyleyen $O ̈ 10$ ise düşüncesini “Kanada'da çok göçmen var, üzerinde durmadık geçen sene." ifadesi ile gerekçelendirmiştir.

\section{Bulgu 8. Kanada Programı’ndaki tarih derslerinin katkılarına iliş- kin görüşleri}

Kanada Programı'ndaki tarih derslerinin katkılarıyla ilgili olarak öğrenciler, Kanada hakkında bilgi edinme (Ö16, Ö2, Ö13), Kanada tarihini öğrenme (Ö2, Ö19, Ö5), farklı bakış açılarını görme (Ö5, Ö7, Ö8, Ö9, Ö14, Ö11, Ö3), daha fazla bilgi edinme (Ö2, Ö17) dünya hakkında 
bilgi edinme (Ö3, Ö12), araştırma ve sunum becerisi kazanma (Ö18) şeklinde ifade etmişlerdir.

“Kanada hakkında bilgi edindiklerini” söyleyen öğrencilerden Ö16 “Kanada’nın çok fazla tarihi olmasa da coğrafyası, iklim çeşitleri hakkında bilgi ediniyorum. Çok soğuk bir ülke, eyaletlerin Fransa ve Kanada kesimlerinin (Quebec-Kanada) arasında toprak tartışması var. Buradaki Türk - Kürt tartışmalarına benziyor. Böylece Türkiye ve Kanada'yı karşılaştırmama yardımcı oldu.”. Burada öğrencinin kültürler arası eğitim sayesinde farklı iki toplumun, kendi sınırları içinde olan toprak sorununu karşılaştırdığı görülmektedir. Farklı bir kültürün eğitimini alarak o ülkenin sorunlarını, öğrencinin kendi ülkesinin yaşadığı problemler ile karşılaştırması dünyada 1960'lardan itibaren çalışılmaya başlanan "Karşılaştırmalı Tarih” alanına -öğrenci gözüyle de olsa- hizmet ettiği söylenebilir (Yalansı, 2009). Ö13 “Kanada'da okumayı düşünüyorum. Bu program bize Kanada’yı ögretiyor" şeklinde düşüncesini ifade etmiştir.

“Kanada tarihini öğrenme” şeklinde ifadede bulunan öğrencilerden Ö19 düşüncelerini “Çoğumuz Kanada'ya üniversiteye gitmek istediğimiz için oranın tarihini bilmek önemli. En azından ne olacă̆ını bilirsiniz, onların size karşı reaksiyonunu bilirsiniz” şeklinde dile getirerek Genç ve Eryaman'ın “Toplumların ve bireylerin, küreselleşmenin doğuracağı muhtemel sonuçlara karş1lık önlem alabilecek ve değişimlerden yarar sağlayabilecek yetilere sahip olması gerekmektedir" (2007, s.99) görüşünü doğrulamaktadır.

Kanada Programı'ndaki tarih derslerinin kendilerine farklı bakış açısını kazandırdığını düşünen öğrencilerin ifadeleri ise şu şekilde olmuştur. Ö11 “Dünya savaşlarını öğreniyoruz. Bu savaşlara iki taraftan bakabiliyoruz. Hem Türk Programından hem Kanada Programından bakabiliyoruz”, Ö5 “Dünyaya farklı bakış açısından bakmayı öğreniyoruz. Farklı bir ülkenin insanı olarak düşünmeyi öğreniyoruz. Kanada tarihi 
o kadar derin olmasa da hakkında bir şeyler biliyor olmak sonuçta biz orada okumayı planlyyoruz, bir şeyler biliyor olarak gidecek olmak insana huzur veriyor en başta." Kültürler arası eğitimin gereklerinden biri olan kültürün benimsenmesi ve yaşatılması konusu "Farklı bir ülkenin insanı olarak düşünmeyi ögreniyoruz” şeklinde belirtilmiştir. Bu durum kişinin kendini, yaşadığ̣ ya da içinde bulunacağı toplumun kültürünün bir parçası olarak görmesi gerçeğiyle ilişkili sayılabilir. Aynı zamanda bu soruya benzer yanıt vererek yabancı bir ülkede yaşamanın zorluklarını, daha önce o ülke hakkında bilgi sahibi olarak aşılabileceğini vurgulamıştır. Kültürler arası eğitim ile öğrencilerin algılarının ve kabullerinin yeni ortama göre düzenlenmesini gerçekleştirerek “yabancı” olma korkusundan ve durumundan kurtuldukları söylenebilir (Bolovan, 2009).

“Kanada Programı'nda bulunan tarih dersleri aracılığıyla daha fazla bilgi edindiğini” söyleyen öğrencilerden Ö17 düşüncesini “Daha fazla fikir edindim. Sohbet ve tartışmalarla daha geniş fikrim oldu, çevreme daha rahat yansitabiliyorum" şeklinde, Ö2 ise "Insan haklarını, tarihini öğreniyorsun.” şeklinde ifade etmiştir.

"Kanada Programında bulunan tarih dersleri aracılığıyla dünya hakkında bilgi edindiğini” söyleyen öğrencilerden Ö3 “hem Türk programında hem de Kanada Programindaki dersleri görüyoruz. Íkisinin de anlatmak istediği şeyler aynı ve ikisi de kendince bir şeyler öğretmeye çalışıyor. Kendi ülkesi hakkında bilgi veriyor. Başka ülkeler hakkında bilgi veriyor. Onlar da barışı savunuyor. Tek bir taraftan değil başka taraflardan aldı̆̆ım barış isteği birleşiyor.” Ö12 ise "Öğrendikçe başka ülkelerin tarihinden bilgi allyoruz. Şu ana kadar öğrendiğim tarih Türk tarihiydi." demiştir.

Ö18 ise "araştırma ve sunum yapabilme yetisi" kazandığını belirtmiştir.

Öğrencilerden Ö10 ise “Coğrafi terimlerin İnilizcesini öğrendim, 
bu sene başka katkısı olmadl. Geçen sene genel kültür vardl. Ağaçlı Projesi kişisel gelişim için önemliydi." diyerek 10. sınıftaki programı eleştirmiştir.

\section{Bulgu 9. Kanada ve Türk Programında tarih derslerinin işlenişi ve müfredatına ilişkin öğrencilerin görüşleri}

Kanada ve Türk Programında tarih derslerinin işlenişisi ile ilgili olarak 7 öğrenci düşüncesini ifade etmiştir. Bu ifadelerde Türk Programının ağır/ detaylı olması (Ö5, Ö16, Ö17), ele aldığ1 konularla (Ö7, Ö14, Ö11) ile ilgili ifadelerin bulunduğu tespit edilmiştir. Bir öğrenci ise her iki ülke programını da eleştirmiştir.

Türk Programının ağır olmasıyla ilgili olarak Ö5 "Türk tarihi çok öncelerden başlıyor, dolayısıyla çok sıkışık bir program, 4 ya da 5 yılda olsa gerçekten çok sıkışık. Ve konudan konuya atlamak zorundayız. Öğrenimi daha zor bir ders Türk tarihi. Kanada tarihi daha güncel, öyle olunca yakalamak daha kolay oluyor. Çok fazla değinilen bir şey yok. Öğrenimi daha kolay.", Ö16 ise "7 ve 8. sınıfta Türk Programındaydım. Ama bana fayda sağlamad, ders çalışmaktan başka bir şey yapmadım, ama en çok 30 aldım. Şu anda burada o çalışmayı yapsaydım notlarım 100 bile olabilirdi. Ama şimdi hem çalışıyorum hem de sosyal hayatıma, kendime vakit ayırıyorum. Bunlar da ilerde iş hayatımda çok önemli şeyler, sosyal hayatımızın olması gerekiyor. Ama Türk Programı bunu sağlamıyor, tam tersine aile sorunları, not kavgaları oluyor." Ö17 ise "Türk Programı daha detaylv ve daha zor. Ama zor da olsa daha rahat anlaşıllyor. Kanada tarihinde çok derine inilmiyor” demiştir.

Ele aldığı konularla ilgili olarak Ö7 "Kanada Programı daha yatkın bana. Türk tarihi Osmanlı'dan ve Türk tarihinden bahsederken Kanada tarihi genel olarak dünya tarihine baklş atıyor Kanada tarihi üzerinden", demiş, Ö11 ise "Kanada sadece kendi ülkesini anlatıyor. Türk tarihinde Osmanlı'yı, İngiltere'yi Fransa'yı görüyoruz” demiştir. 
Her iki ülke programını da eleştiren Ö10 ise "Bilmiyorum. Türk programında Türk tarihi görülüyor. Yetersiz buluyorum. Kanada da yetersiz. İkisinde de ülkelerin tarihinden bahsedilip projeler yapılsin isterdim. Daha verimli olurdu öğrenciler için” diyerek düşüncesini dile getirmiştir.

Kanada ve Türk Programını tarih derslerinin gerçekçiliği ile ilgili olarak 12 öğrenci düşüncesini dile getirmiştir. Bu öğrencilerden her ikisini de gerçekçi bulanlar (Ö2, Ö9), Türk Programını gerçekçi bulanlar (Ö4, Ö3, Ö5, Ö19, Ö11, Ö18, Ö12, Ö13, Ö14) ve tarafs1z kalan öğrenciler (Ö8) olduğu görülmüştür.

Her ikisinin de gerçekçi olduğunu söyleyen öğrencilerden Ö9 “İkisi de gerçekçi. Türk Programında Osmanlı’yı öğreniyoruz, bu öğrenilmesi gereken bir şey, Kanada Programında dünyayı öğreniyoruz" demiştir. Ö2 ise "İkisi de gerçekçi. Ama Türk Programı daha gerçekçi. Türküm çünkü ve bazl şeyleri biliyorum, bildiğim için Türk tarihi daha gerçekçi." diyerek her ikisini de gerçekçi bulduğunu belirtmesine rağmen yine de Türk programının daha da gerçekçi geldiğini vurgulamıştır.

Türk müfredatını daha gerçekçi bulan öğrencilerden $O$ 4 “Türk müfredatı daha gerçekçi çünkü daha geniş bir müfredatı kapsıyor ve objektif. Türklerde kendimizi anlatıyoruz. Onlarda farklı milletler de var. Onlarda kitaptan kitaba değişiyor. Farklı kaynaklara göre değişiyor. Tarihî gerçeklik değişiyor” demiştir. Ö19 “Türk programı daha gerçekçi çünkü o tarihin içinde yaşıyorum. Daha iyi anlayabiliyorum. Kanada'ya gittiğimde eski bir tane bina göremedim. Burada tarihin içinde yaşlyorsunuz. Onlar buraya geldiğinde çok şaşırıyorlar" demiştir. Ö18 ise “Türk tarihi. Çünkü Kanada'ya göre daha kapsamlı işleniyor.” diyerek düşüncesini açıklamıştır. Türk Programının daha gerçekçi gelmesinin nedeni Türk olmaları ve uzun zamandır Türk tarihi görmeleriyle açıklayan öğrencilerin bulunduğu da tespit edilmiştir. Bu öğrencilerden $O ̈ 3$ 
"Tabii ki Türk. Kendimi bildim bileli Türk tarihi işliyoruz. Ve bu sene Kanada tarihi öğrendik ama Türk tarihi." Ö13 ise "Türk Programı çünkü ben Türküm ve daha anlaşılır geliyor" şeklinde ifade etmiştir. Ö8 ise "İki tarafta da farklılıklar var. Ama taraf seçemem açıkçası, çünkü Türk tarihi başlı başına olay, kendi ülkemin tarihini öğreniyorum.” şeklinde düşüncelerini ifade etmiştir.

Genel olarak bakıldığında öğrenciler Kanada Lisesi Diploma Programı'nda konuların tarafsız işlendiğini çeşitli yerlerde vurgulamışlardır. Müfredatın tarafsız işlenmesinin bunda etkili olduğu söylenebilir. Ancak asıl ve daha önemli etken, öğretmenlerin konulara daha tarafsız yaklaşabilmeleridir. Bu program kapsamında bir dünya vatandaşı yetiştirme hedefinde olan öğretmenler burada dünya vatandaşı olan bir eğitimci olarak görevlerini yapmalarını anlamak mümkündür. Bu kültürler arası eğitimde öğretmenin en önemli rollerinden biridir.

\section{Sonuç}

Türkiye'de kültürler arası eğitim adına öğrencilerini dünya vatandaşı olarak yetiştirme isteğinde olan bazı ortaöğretim okullarının gerekli uluslararası bağlantıları kurarak son yıllarda bunu belli ölçülerde gerçekleştirebildikleri gözlenmiştir. Bu çerçevede çalışmamızın odağ1 olan Kanada Lise Diploması Programı'nda okuyan lise öğrencilerinin tarih eğitimi gibi daha çok kültürel temelleri ön planda bir dersi nasıl algıladıkları ve gördükleri incelenmiştir.

Programda yer alan derslere öğrencilerin bakışının genelde programın pratik sonuçları itibarıyla biçimlendiği görülmüştür. Programda Kanada'daki yaşam biçimlerinden, kültürlerden bahsedilmesi ve eğitimin Kanadalı öğretmenlerce verilmesiyle öğrencilerin yüksek öğrenimleri boyunca bir yabancılık yaşamalarına engel olmasının amaçlanmış olması da bunu göstermektedir. Böylelikle öğrencilerin daha ülkeye gitmeden 
kendi kültürleri ile Kanada kültürünü harmanlayarak farklı olana sayg1 gösterme ve kabullenme, birlikte yaşama gibi daha çok uluslararası değerlerin benimsenmesi beklenmiştir. Bu çerçevede Kanada Lise Diploması Programı'nda okuyan lise öğrencilerinin, üniversite tercihlerini Kanada üniversitelerinden yana yapacakları için program dâhilinde aldıkları derslere genelde bu yarar çerçevesinde yaklaşma eğilimlerinde oldukları görülmüştür.

Programda okuyan öğrencilerin Kanada okul programı tarih eğitimi süreçlerine ilişkin durumu genel olarak olumlu bulduklarını söylemek mümkündür. Derslerde tarih alanıyla sınırlı kalınmayarak disiplinler arası yaklaşım ile öğrencilerin hem derse katılımlarının arttırıldığı hem de diğer derslerde öğrendiklerini farklı formlarda kullanabilme şansının verildiği anlaşılmaktadır. Öğrencilerin genelinin dile getirdiği bir diğer farklılık ise salt ulusal bir bakış yerine Kanada tarihinin dünya tarihi çerçevesinde ele alındığı, bunun da daha gerçekçi bir bakış oluşturduğu, daha barışçı1 mesajları içerdiğidir. Bu durumun kültürler arası eğitimin "olmazsa olmaz" amacıyla ilişkili olduğu açıktır.

Kanada Programı tarih derslerinde eğlenceli, güncel, ilgi çekici, hayatla bağlantılı, proje temelli, başka kültür ve tarihleri tanımaya dönük, tartışmacı/sorgulamacı, materyal geliştirmeye dönük bir yaklaşım çerçevesinde öğretimin yapıldığ 1 görülmüştür. Bu durumun Türkiye'de yeni öğretim programlarıyla yapılmak istenen, ilköğretimde büyük ölçüde başarılmış olmasına rağmen ortaöğretimde ne yazık ki ulaşılamayan yapılandırmacı yaklaşımın muhtemel imkânlarıyla paralel olduğu söylenebilir.

Öğrencilerin genel bir değerlendirmeyle başka bir ülkenin tarihini geniş bir bakış açısı ve çağdaş öğretim süreçleri çerçevesinde öğrenmelerine rağmen Türk tarihine yüksek derecede saygı duydukları da görülmüştür. Türkiye'deki tarih derslerinde genelde daha çok "biz" merkezli olmasının ve tartışmalı konuların konuşulmaması bir eksiklik 
olarak görülmesine rağmen Türk tarihi, öğrencilerin kimliksel aidiyet hislerinden dolayı ayrıcalıklı yerini korumaktadır. Bu durum Türkiye'deki tarih derslerinin öğretimsel olarak planlama-uygulama-ölçme değerlendirme açısından pek çok sorun yaşandığının fark edilmesine rağmen millî birlik ruhunun başarılı bir biçimde verildiğinin göstergesi sayılabilir. Bu açıdan kültürler arası eğitim, kendi kültürü ve tarihini iyi öğrendikten sonra başka kültürleri tanımak ve bireylerin düşünce dünyalarını zenginleştirerek, dünya ile bütünleşmelerini sağlaması yönüyle kıymetli sayılabilir.

Araştırma sonucunda öğrencilerin yaklaşımlarından hareketle Türkiye'deki tarih eğitiminin öğretimsel sorunlarının başında bireylerin kendi yaşamları ile tarih arasında bir ilişki kuramadıkları içeriği edinmelerinin beklenmesi olduğu söylenebilir. Kanada Programı'nda yer alan tarih derslerinin bu anlayışın tersine bireylerin sosyal anlamda yaşadıkları sorunlara ve çözüm yollarına odaklanması Türkiye’ye ilişkin öğretimsel bir öneri olarak değerlendirilebilir. Böylece Türkiye'de de Türk tarihinin dünya tarihi içinde ele alınarak bireylere daha küresel ve anlamlı bir tarih eğitimi şansının sunulması mümkün olabilecektir. Bunun için başta öğretim programları olmak üzere, ders kitapları ve hizmet içi eğitim dâhil olmak üzere öğretmen eğitiminde düzenlemeye gidilmesi bir zorunluluk olarak durmaktadır. 


\section{Kaynakça}

Akçay, R. (2003). Küreselleşme, eğitimsel yoksunluk ve yetişkin eğitimi, Milli Ĕgitim Dergisi, 159.

Aksoy, N. (2001). Çokkültürlülük üstüne. N. Aksoy, (Ed.), Modernleşme ve çokkültürlülük içinde $(44,50)$. İstanbul: Helsinki Yurttaşlar Derneği.

Asser, H., Trasberg, K. ve Vassilchenko, I. (2004). Intercultural education in the curriculum: Some comparative aspects from the Balticand Nordic Countries. Intercultural Education, 15 (1), 33-43.

Balay, R. (2004). Küreselleşme, bilgi toplumu ve eğitim. Ankara Üniversitesi Ĕ̆itim Bilimleri Fakültesi Dergisi, 37 (2), 61-82.

Bolovan, S. P. (2009). Opportunities of the intercultural education in teaching-learning history. Acta Didactica Napocensia, 2 (1), 35-42.

Davcheva, L. ve Katsarska, M. (2006). Country update: Recent practices of intercultural education in Bulgaria. Intercultural Education, 17, (5), 517-521.

Demir, A. ve Demir, S. (2009). Erasmus programının kültürler arası diyalog ve etkileşim açısından değerlendirilmesi (Öğretmen adaylarıyla nitel bir çalışma). Uluslararası Sosyal Araştırmalar Dergisi, 2 (9), 95-105.

Demircioğlu İ. H. ve Tokdemir M. A. (2008). Değerlerin oluşturulma sürecinde tarih eğitimi: Amaç, işlev ve içerik. Değerler Eğitimi Dergisi, 6 (15), 69-88.

Dördüncü Demokratik Eğitim kurultayı, (2004). “Çok Dilli, Çok Kültürlü Toplumlarda Eğitim”. Ankara: Eğitim-Sen Yayınları. 09\07\2011 tarihinde http://www. daplatform.com adresinden alınmıştır.

Ensaroğlu, Y. (2001). Modernleşme sürecinde çokkültürlülük. N. Aksoy, (Ed.), Modernleşme ve Çokkültürlülük içinde (85-88). İstanbul: Helsinki Yurttaşlar Derneği.

Erdoğan, İ. (2002). Eğitimde Değişim Yönetimi. Ankara: Pegem Yayıncılık.

Genç, S. ve Eryaman, Y. (2007). Değişen değerler ve yeni eğitim paradigması. Sosyal Bilimler Dergisi, 9 (1), 89 -102.

İnsel, A. (2001). Çokkültürlülük, çokkimliklilik, çoğulculuk. N. Aksoy, (Ed.), Modernleşme ve Çokkültürlülük içinde (100-104). İstanbul: Helsinki Yurttaşlar Derneği.

Koca, F. ve Şimşek A. (2009). Ortaöğretim Öğrencilerinin Tarih Derslerinde Yaptıkları Projelerde Ortaya Çıkan Sorunlar: Proje Ürünleri Üzerinden Bir Okuma. $I V$. 
Sosyal Bilimler Eğitimi Kongresi, (7-9 Ekim), Marmara Üniversitesi Atatürk Eğitim Fakültesi, İstanbul.

Kuş, E. (2007). Nicel-nitel araştırma teknikleri. Ankara: Anı Yayıncılık.

Küçük, S. (2011). Kültürler arası öğrenme üzerine bir kavram-model denemesi ve Türkçe ders kitapları. Tübar, 29, 227-260.

Laçiner, Ö. (2001). Çokkültürlülük. N. Aksoy, (Ed.), Modernleşme ve Çokkültürlülük içinde (157-160) İstanbul: Helsinki Yurttaşlar Derneği.

Nohl, A. M. (2009). Ders kitaplarında kültürler arası eğitim imkanları. Eğitim Bilim Toplum Dergisi, 7, (28), 59 -73.

Paleologou, N. (2004). Intercultural education and practice in Greece: Needs for bilingual intercultural programmes. Intercultural Education, 15 (1), 317- 329.

Posavec, K. ve Hrvatic, N. (2000). Intercultural Education and Roma in Croatia. Intercultural Education, 11 (1), 93-105.

Trassberg, K., Asser, H. ve Vassilcheko, L. (2004). Intercultural education in the curriculum: Some comparative aspects from the Baltic and nordic countries. Intercultural Education, 15 (1), 33-43.

Ültanır, G. (2003). Eğitim ve Kültür İlişkisi-Eğitimde Kültürün Hangi Boyutlarının Genç Kuşaklara Aktarılacağı Kaygısı. Gazi Üniversitesi, Gazi Eğitim Fakültesi Dergisi, 23 (3), 291-309.

Yağbasan, M. (2008). Kültürler arası iletişim bağlamında Almanya'daki Türklerin iletişimsel ortamlarının belirlenmesine yönelik bir alan araştırması. Fırat Üniversitesi Sosyal Bilimler Dergisi, 18 (2), 309-332.

Yalansız, N. (2009). Karşılaştırmalı tarih: Tarih öğretiminde yeni bir yaklaşım. Uluslararası Sosyal Araştırmalar Dergisi, 2 (9), 493-498.

Web 1: Avrupa Birliği Erasmus Programı http://www.ua.gov.tr 30/06/2010 tarihinde alınmıștır.

Web 2: Avrupa Birliği Comenius Programı http://www.ua.gov.tr 30/06/2010 tarihinde alınmıştır.

Web 3: International Baccalaureate http://www.ibo.org/mission 09\07\2010 tarihinde alınmıştır. 
Web 4: Kent State Programı http://www.kentstatekoleji.com/tr 09\07\2010 tarihinde alınmıştır.

Yıldırım, A ve Şimşek, H. (2006). Nitel Araştırma Yöntemleri, Ankara; Seçkin Yayıncılık. 